\section{Quaternary Detergents and the Activity of Trypsin and Plasmin}

DURING investigations on antiproteolytic sub. stances an interesting action of two quaternary surface-active agents, namely, cetylpyridinium chloride ('Germidin', Bionova, Ltd., Copenhagen) and lauryl-benzyldimethylammonium chloride ('Rodalon', Ferrosan, Ltd., Copenhagen), was observed.

Mixtures of the quaternary compounds with trypsin (Armour, crystalline, containing not more than 50 per cent magnesium sulphate) and plasmin (human, streptokinase-activated) were tested for fibrinolytic activity by means of the plate method ${ }^{1,2}$. The results are presented in the accompanying graph.

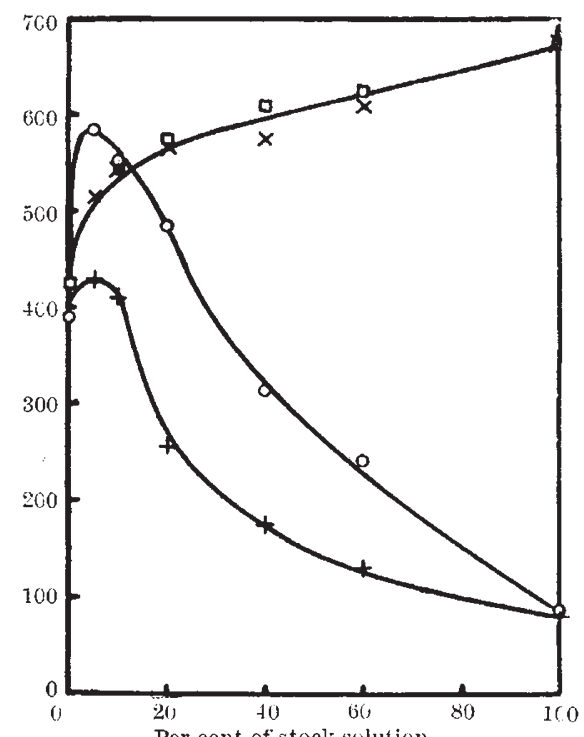

๑)- - Trypsin + 'Rodalon'; $\times-\times-$, trypsin + 'Germidin' : $0-0$-, plasmin + 'Rodalon'; +-+ , plasmin + 'Germidin' Action of cetylpyridinium chloride ('Germidin', 1 per cent stock
solution) and lauryl-benzyldimethylammonium chloride ('Rodalon', 1 per cent stock solution) on the fibrinolytic activity of equal volumes of enzyme solution. Abscissa: Concentration of quaternary compound added in per cent of stock solution. Ordinate: Eibrinolytic activity recorded as the product of two diameters of the lysed zones

It is seen that the fibrinolytic activity of trypsin is increased considerably by the addition of the quaternary compounds. Plasmin shows an increase in activity in the presence of very small concentrations of the compounds, while larger amounts inhibit. These results stress the difference between trypsin and plasmin as proteolytic enzymes. Chymotrypsin (Armour, crystalline, 50 per cent magnesium sulphate) was slightly inhibited. An Aspergillus protease ${ }^{3}$ (courtesy of Dr. W. G. Crewther, Melbourne) was activated slightly.

Our experiments have shown that proteolytic enzymes may be characterized and grouped according to the influence of a number of antiproteolytic substances. These investigations will be published in detail elsewhere.

\section{Tage Astrup}

Biological Institute, NORMA ALKJ IERSIG

Carlsberg Foundation,

Copenhagen. May 8.

${ }^{1}$ Permin, P. M., Acta Physiol. Scand., 20, 388 (1950), 2 Astrup, T., Crockston, J., and MacIntyre, A., Acta Physiol. Scand.,
21, $238(1950)$.

${ }^{3}$ ('rew'ther, W. G., and Iennox, F. G., Nature, 185, 680 (1950).
Effect of Temperature on the $R_{F}$ Values of the Amino-acids during Paper Chromatography with Solvents completely Miscible with Water

Consden et al. ${ }^{1}$ observed that in the case of phenol saturated with water as the developing solvent, $R_{F}$ values of amino-acids increase with increase of temperature, since the water-content of phenol varies directly with temperature within the range studied. The reverse is the case with collidine, the watercontent of which decreases with increase of temperature. The water-content of solvents which are completely miscible with water can be suitably adjusted, the phase-composition remaining unaffected by temperature. If the change in phasecomposition of the developing solvent is the only cause of alterations of $R_{F}$ values with temperature, they should be independent of temperature in case of miscible solvents. That this is not so will be clear from the following.

The miscible solvents employed were pyridine, acetone and isopropyl alcohol. Since these solvents are highly volatile, the ascending method $^{2}$ of paper chromatography was followed, using throughout Whatman No. 1 filter paper. The positions of the amino-acids on the chromatogram were, as usual, indicated with ninhydrin. The range of variation in temperature during a particular experiment did not exceed half a degree. The accompanying table records the $R_{F}$ values at different temperatures of four amino-acids out of a large number I have investigated.

\begin{tabular}{|c|c|c|c|c|c|c|}
\hline \multirow{3}{*}{$\begin{array}{c}\begin{array}{c}\text { Devcloping } \\
\text { solvent }\end{array} \\
\begin{array}{c}\text { Acetone-water } \\
(7: 3 \text { by vol. })\end{array}\end{array}$} & \multirow{3}{*}{$\begin{array}{l}\text { Amino-acids } \\
\text { Aspartic acid } \\
\text { Glycine } \\
\text { Proline }\end{array}$} & \multicolumn{5}{|c|}{$\begin{array}{c}R^{\circ} \mathrm{C} \cdot 15^{\circ} \mathrm{C} \text { values at } 26^{\circ} \mathrm{C} .25^{\circ} \mathrm{C} .30^{\circ} \mathrm{C} .\end{array}$} \\
\hline & & 0.23 & $0 \cdot 31$ & $0 \cdot 38$ & 0.53 & 0.58 \\
\hline & & $\begin{array}{l}0.26 \\
0.46\end{array}$ & $\begin{array}{l}0.34 \\
0.49\end{array}$ & $\begin{array}{l}0.36 \\
0.51\end{array}$ & $\begin{array}{l}0 \cdot 51 \\
0.65\end{array}$ & $\begin{array}{l}0 \cdot 51 \\
0.69\end{array}$ \\
\hline & Phenylalanine & 0.53 & 0.63 & 0.64 & 0.72 & 0.72 \\
\hline \multirow{4}{*}{$\begin{array}{l}\text { Pyridine-water } \\
(7: 3 \text { by vol. })\end{array}$} & Aspartic acid & 0.25 & $0 \cdot 27$ & $0 \cdot 33$ & 0.25 & 0.32 \\
\hline & Glycine & $0 \cdot 34$ & $0 \cdot 35$ & $0 \cdot 38$ & $0 \cdot 36$ & $0 \cdot 36$ \\
\hline & Prol & 0.51 & 0.56 & $0 \cdot 60$ & 0.55 & 0.52 \\
\hline & Phenylalanine & 0.63 & 0.70 & $0 \cdot 71$ & $0 \cdot 72$ & 0.68 \\
\hline \multirow{4}{*}{$\begin{array}{l}\text { Isopropyl } \\
\text { alcohol--water } \\
\text { ( } 7: 3 \text { by vol.) }\end{array}$} & Aspartic acid & $0 \cdot 12$ & $0 \cdot 13$ & 0.17 & 0.28 & $0 \cdot 17$ \\
\hline & Glycine & 0.20 & 0.23 & 0.27 & $0 \cdot 30$ & 0.26 \\
\hline & Prolin & 0.32 & $0 \cdot 40$ & 0.45 & 0.47 & 0.44 \\
\hline & Phenylalanine & 0.47 & 0.51 & 0.56 & 0.57 & 0.55 \\
\hline \multirow{4}{*}{$\begin{array}{l}\text { Isopropyl } \\
\text { alcohol--water } \\
\text { (9:1 by vol.) }\end{array}$} & Aspartic acid & & & & & \\
\hline & Glycine & 0.02 & 0.02 & 0.03 & $(0 \cdot 04$ & 0.05 \\
\hline & Proline & $0 \cdot 10$ & $0 \cdot 11$ & $0 \cdot 11$ & 0.13 & $0 \cdot 15$ \\
\hline & Phenylalanine & $0 \cdot 17$ & $0 \cdot 18$ & $0 \cdot 19$ & $0 \cdot 20$ & 0.25 \\
\hline
\end{tabular}

These results indicate that in most eases the $R_{F}$ values increase with rise of temperature, except in the case of pyridine-water at $25^{\circ} \mathrm{C}$. and isopropyl alcohol-water $(7: 3)$ at $30^{\circ} \mathrm{C}$. At these two temperatures the $R_{F}$ values show a decrease instead of an increase compared with those at preceding tempera. tures. A decrease of the partition coefficient at higher temperatures would partly explain an increase of $R_{F}$, assuming a constant value for the ratio of areas of cross-section of the mobile and immobile phases.

The decrease in $R_{F}$ values in the case of pyridinewater at $25^{\circ} \mathrm{C}$. and isopropyl alcohol-water $(7: 3)$ at $30^{\circ} \mathrm{C}$. is contrary to what one expects from the above reasoning. It is perhaps necessary to take into account a large number of factors involved in paper chromatography which are likely to be influenced by temperature. They include water-adsórption by cellulose, compositions of the phases, affinity of the solvent and solute molecules for cellulose and the solvating power of the liquids employed. A detailed study for evaluating the most likely factors is in progress. 